\title{
Evaluation of Mechanical Properties of Aluminium Alloy2024 Reinforced with Silicon Carbide and Fly Ash Hybrid Metal Matrix Composites
}

\author{
${ }^{1}$ Mahendra Boopathi, M., ${ }^{2}$ K.P. Arulshri and ${ }^{3}$ N. Iyandurai \\ ${ }^{1}$ Department of Mechanical Engineering, \\ CMS College of Engineering and Technology, Coimbatore-641 032, TamilNadu, India \\ ${ }^{2}$ Department of Mechanical Engineering, \\ KPR Institute of Engineering and Technology, Coimbatore-641 407, TamilNadu, India \\ ${ }^{3}$ Department of Physics, Thiruvalluvar Govt Arts College, Rasipuram, Namakkal-637 401, TamilNadu, India
}

Received 2012-10-07; Revised 2012-10-22; Accepted 2013-04-16

\begin{abstract}
Materials are frequently chosen for structural applications because they have desirable combinations of mechanical characteristics. Development of hybrid metal matrix composites has become an important area of research interest in Materials Science. In view of this, the present study focuses on the formation of aluminium-Sic-fly ash hybrid metal matrix composites. The present study was aimed at evaluating the physical properties of Aluminium 2024 in the presence of silicon carbide, fly ash and its combinations. Consequently aluminium metal matrix composite combines the strength of the reinforcement with the toughness of the matrix to achieve a combination of desirable properties not available in any single conventional material. The compositions were added up to the ultimate level and stir casting method was used for the fabrication of aluminium metal matrix composites. Structural characterization was carried out on metal matrix composites by x-ray diffraction studies and optical microscopy was used for the micro structural studies. The mechanical behaviors of metal matrix composites like density, tensile strength, yield strength, elongation and hardness tests were ascertained by performing carefully designed laboratory experiments that replicate as nearly as possible the service conditions. In the presence of silicon carbide and fly ash $[\mathrm{SiC}(5 \%)+$ fly ash $(10 \%)$ and fly ash $(10 \%)+\mathrm{SiC}(10 \%)]$ with aluminium, it was fairly observed that the density of the composites was decreased and the hardness was increased. Correspondingly, the increase in tensile strength was also observed but elongation of the hybrid metal matrix composites in comparison with unreinforced aluminium was decreased. The aluminium-SiC-fly ash hybrid metal matrix composites significantly differed in all of the properties measured. Aluminium in the presence of $\mathrm{SiC}$ (10\%)-fly ash (10\%) was the hardest instead of aluminium-SiC and cluminium-fly ash composites. The study can be further extended by evaluating the wear and corrosion of the resultant material.
\end{abstract}

Keywords: Aluminium, Fly Ash, Silicon Carbide, Hybrid Metal Matrix Composites

\section{INTRODUCTION}

Discontinuously reinforced aluminium matrix composites are fast emerging as engineering materials and competing with common metals and alloys. They are gaining significant acceptance because of higher specific strength, specific modulus and good wear resistance as compared to ordinary unreinforced alloys

Corresponding Author: N. Iyandurai, Department of Physics, Thiruvalluvar Govt Arts College, Rasipuram, Namakkal-637 401, TamilNadu, India 
(Sarkar and Singh, 2012). Reinforcing particles used in this study are silicon carbide and fly ash particles which are added externally.

Aluminium alloy 2024 has good machining characteristics, higher strength and fatigue resistance than both 2014 and 2017. It is widely used in aircraft structures, especially wing and fuselage structures under tension. It is also used in high temperature applications such as in automobile engines and in other rotating and reciprocating parts such as piston, drive shafts, brake rotors and in other structural parts which require light weight and high strength materials (Ibrahim et al., 1991). Aluminium is also a ubiquitous element and one of the trace elements with moderate toxic effect on living organism (Buraimoh et al., 2012). One of the main drawbacks of this material system is that they exhibit poor tribological properties. Hence the desire in the engineering community to develop a new material with greater wear resistance and better tribological properties, without much compromising on the strength to weight ratio led to the development of metal matrix composites (Sinclair and Gregson, 1997; Sannino and Rack, 1995).

Silicon carbide is a compound of silicon and carbon with a chemical formula SiC. Silicon carbide was originally produced by a high temperature electrochemical reaction of sand and carbon. Any acids or alkalis or molten salts up to $800^{\circ} \mathrm{C}$ do not attack silicon carbide. In air, $\mathrm{SiC}$ forms a protective silicon oxide coating at $1200^{\circ} \mathrm{C}$ and is able to be used up to $1600^{\circ} \mathrm{C}$. The high thermal conductivity coupled with low thermal expansion and high strength gives this material exceptional thermal shock resistant qualities. Silicon carbide ceramics with little or no grain boundary impurities maintain their strength to very high temperatures, approaching $1600^{\circ} \mathrm{C}$ with no strength loss. Chemical purity, resistance to chemical attack at temperature and strength retention at high temperatures has made this material very popular as wafer tray supports and paddles in semiconductor furnaces. It is an excellent abrasive and has been produced and made into grinding wheels and other abrasive products for over one hundred years. Today the material has been developed into a high quality technical grade ceramic with very good mechanical properties. It is used in abrasives, refractories, ceramics and numerous high-performance applications (Neudeck, 1992).

Fly ash is one of the most inexpensive and lowdensity reinforcement available in large quantities as solid waste by-product during combustion of coal in thermal power plants. Coal Combustion Products (CCP) is produced in coal-fired power stations, which burn either hard or brown coal. Due to the mineral component of coal and combustion technique, Fly Ash (FA) is produced (Gatima et al., 2005). In the US alone each year over 118 million tons of coal combustion products are produced. In India the stature was about 90 million ton during 1995 and is likely to exceed 140 million tons in 2020. Percentage utilization of fly ash differs between countries between $95 \%$ in Belgium and the Netherlands and $3 \%$ in India in the 1990s (Ulrichs et al., 2009). The utilization of fly ash instead of dumping it as a waste material can be both on economic and environmental grounds (Mohan et al., 2012). There is already a vast body of information on utilization of Fly Ash (FA) in building/construction, production of aggregates and more recently for agriculture (Brian et al., 2003).

Composites are engineered or naturally occurring materials made from two or more constituent materials with significantly different physical or chemical properties that remain separate and distinct within the finished structure. The bulk material forms the continuous phase that is the matrix (e.g., metals, polymers) and the other acts as the discontinuous phase that is the reinforcements (e.g., ceramics, fibers, whiskers, particulates). While the reinforcing material usually carries the major amount of load, the matrix enables the load transfer by holding them together (Pai et al., 2004).

The challenges and opportunities of aluminium matrix composites have been reported much better to that of its unreinforced counterpart (Surappa, 2003). The addition of reinforcing phase significantly improves the tribological properties of aluminium and its alloy system. The thinking behind the development of hybrid metal matrix composites is to combine the desirable properties of aluminium, silicon carbide and fly ash. Aluminium have useful properties such as high strength, ductility, high thermal and electrical conductivity but have low stiffness whereas silicon carbide and fly ash are stiffer and stronger and have excellent high temperature resistance but they are brittle in nature (Prabu et al., 2006).

In this study, an attempt has been made to fabricate a hybrid metal matrix composites from commercial silicon carbide and fly ash. Aluminium 2024 is used as matrix material for the fabrication of Al-SiC-fly ash hybrid composite material. Methods available for the production of hybrid metal matrix composites are powder metallurgy, spray deposition, liquid metal infiltration, squeeze casting, stir casting (Nai and Gupta, 2002; Hashim et al., 1999). Though various processing 
techniques available for particulate or discontinuous reinforced metal matrix composites, stir casting is the technique, which is in use for large quantity commercial production. This technique is most suitable due to its simplicity, flexibility and ease of production for large sized components. Hence stir casting method is used in this study.

The objective of the present work is to form the reinforcing phase within the metallic matrix by reaction of silicon carbide, fly ash and its proportions with aluminium in the metallic melt. To increase the wettability, commercially pure magnesium (1.5\%) was added. The composites were characterized with the help of $\mathrm{x}$-ray diffraction methods and optical microscopy. Its density, tensile behavior and hardness were also evaluated.

\section{MATERIALS AND METHODS}

\subsection{Materials}

The matrix material used in the present investigation was pure aluminium. Aluminium was purchased from Perfect Metal Works, Bangaluru, Karnataka, India. Silicon carbide, fly ash and magnesium were commercially available.

\subsection{Experimental Work}

The Stir casting method (also called liquid state method) is used for the hybrid composite materials fabrication, in which a dispersed phase is mixed with a molten matrix metal by means of mechanical stirring. The liquid composite material is then cast by conventional casting methods and may also be processed by conventional metal forming technologies.

In this study, the aluminium-SiC, aluminum- fly ash, aluminium-SiC-fly ash and aluminium-fly ash-SiC metal matrix hybrid composite was prepared by stir casting route (Fig. 1). For this we have chosen 100gm of commercially pure aluminum and desired amount of $\mathrm{SiC}$, fly ash, SiC-fly ash mixtures in powder form. The fly ash and $\mathrm{SiC}$ and their mixture were preheated to $300^{\circ} \mathrm{C}$ for three hours to remove moisture. Pure aluminum was melted in a resistance furnace. The melt temperature was raised up to $720^{\circ} \mathrm{C}$ and then the melt was stirred with the help of a mild steel turbine stirrer. The stirring was maintained between 5 to $7 \mathrm{~min}$ at an impeller speed of $200 \mathrm{rpm}$. To increase the wettability, $1.5 \%$ of pure $\mathrm{Mg}$ was added with all composites. The melt temperature was maintained $700^{\circ} \mathrm{C}$ during addition of $\mathrm{Mg}, \mathrm{SiC}$, fly ash, SiC-fly ash mixture particles. The dispersion of fly ash and other particles were achieved by the vortex method. The melt with reinforced particulates were poured into the preheated permanent metallic mold. The pouring temperature was maintained at $680^{\circ} \mathrm{C}$. The melt was then allowed to solidify in the mould (Fig. 2). The metal matrix hybrid composites that we obtained are shown in the Fig. 3.

\subsection{Microstructural Characterization}

The composites produced were examined by optical microscope to analyze the microstructure. A section was cut from the castings, which is first belt grinded followed by polishing with different grade of emery papers. After that they were washed and again cloth polishing of the sample was done. After etching they were examined for microstructure under optical microscope at different magnifications.

\subsection{X-Ray Diffraction Analysis}

The composites prepared were analyzed with the help of x-ray diffraction technique to check the presence of different compounds in the composites.

\subsection{Mechanical Properties Observation}

\subsubsection{Density}

Density of the composite specimens was obtained experimentally by the Archimedes principle. Theoretical density was calculated applying the rule of mixtures according to the weight fraction of reinforcement.

\subsection{Tensile Behavior}

The tensile testing was done using a computerized UTM testing machine as per the ASTM E-8 standards. The sample rate was $9.103 \mathrm{pts} / \mathrm{sec}$ and crosshead speed $5.0 \mathrm{~mm} / \mathrm{min}$. Standard specimens (Fig. 4) with $36 \mathrm{~mm}$ gauge length were used to evaluate ultimate tensile strength, yield strength and percent elongation. Samples used for the tensile behavior tests are shown in Fig. 5.

\subsection{Hardness}

Bulk hardness measurements were carried out on the base metal and composite samples by using standard Brinell hardness test machine. Brinell hardness measurements were carried out in order to investigate the influence of particulate weight fraction on the matrix hardness. Load applied was $10 \mathrm{~kg}$ and indenter used was square based diamond pyramid. Samples used for the hardness tests are shown in Fig. 6. 


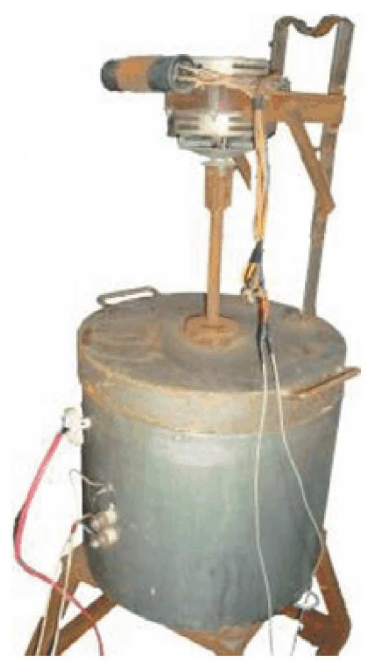

Fig. 1. Stir casting unit

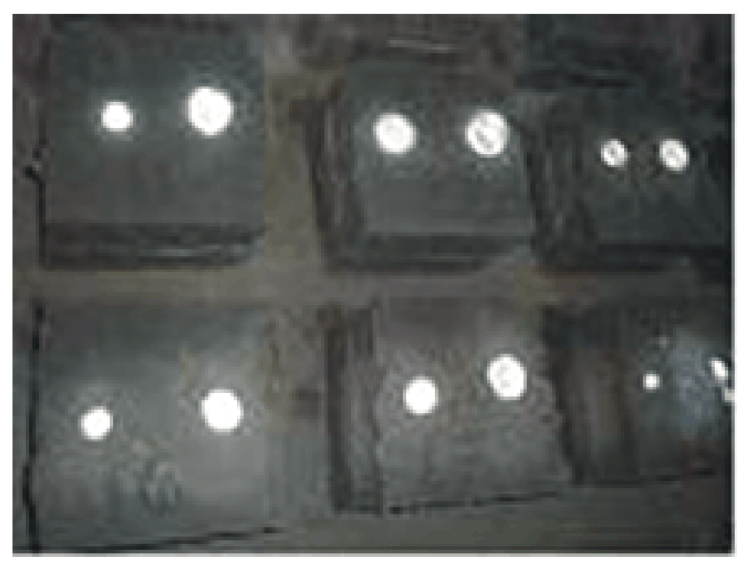

Fig. 2. Saples in the mould

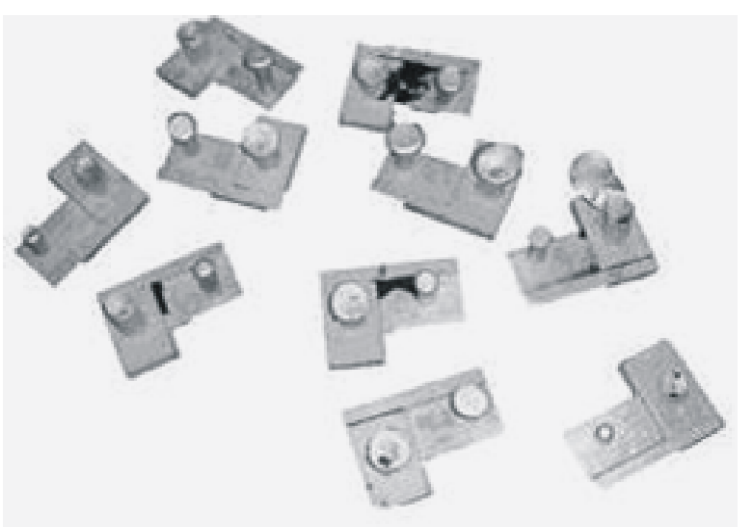

Fig. 3. Samples

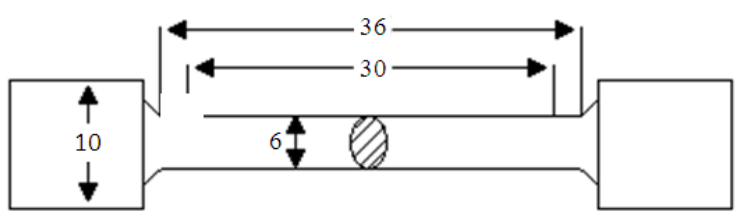

Fig. 4. Standard tensile specimen

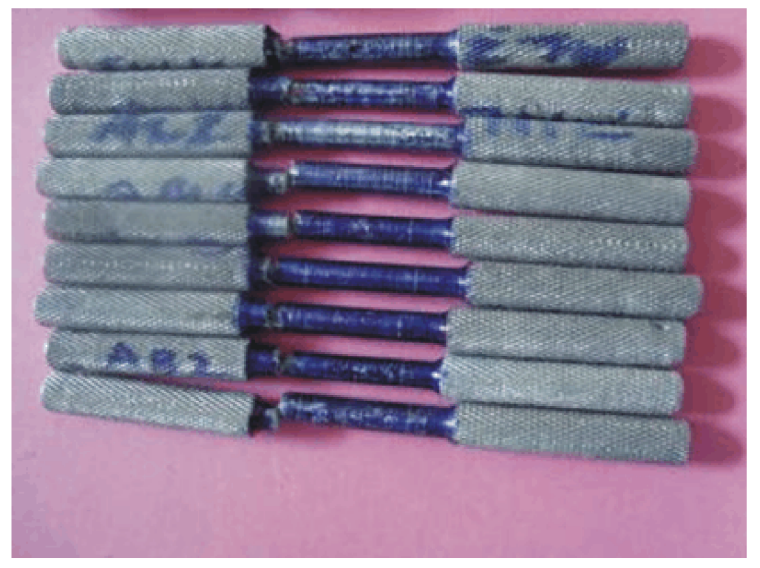

Fig. 5. Samples for the tensile tests

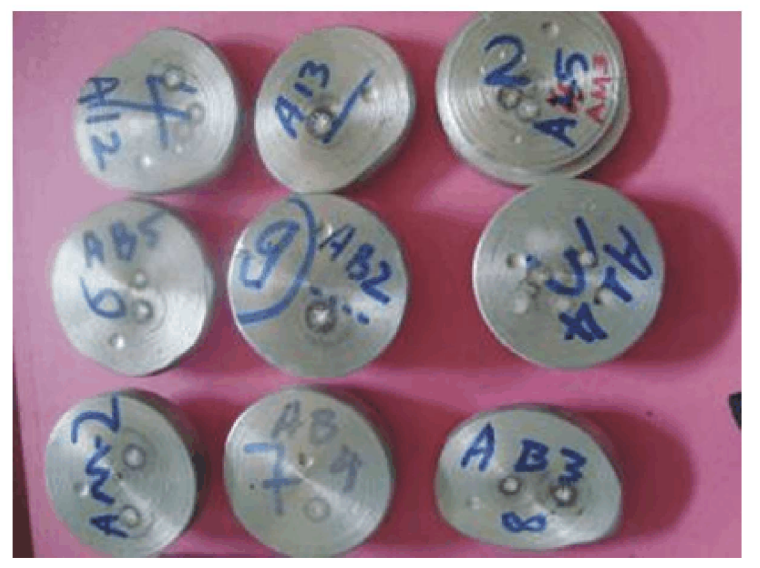

Fig. 6. Samples for the hardness tests

\section{RESULTS AND DISCUSSION}

\subsection{Optical Micrographs of MMCs}

The morphology, density, type of reinforcing particles and its distribution have a major influence on the properties of particulate composites. The variables that govern the distribution of particles are solidification 
rate, fluidity, type of reinforcement and the method of incorporation. It is necessary to distribute particles uniformly throughout the casting during production of particulate composites. The first task is to get a uniform distribution of particles in the liquid melt and then to prevent segregation/agglomeration of particles during pouring and progress of solidification. One of the major requirements for uniform distribution of particles in the melt is its wettability. Addition of magnesium improves the wettability.

The microstructures of the samples, cut from the plate casting at different locations, were observed to study the particle distribution. The optical micrographs of hybrid metal matrix composites are shown in Fig. 715. As shown in the Fig. 7-15, well-formed nodules were observed before etching and grain boundaries were observed after etching process.

It is observed that particles were not uniformly distributed in the case of $\mathrm{Al} /(5 \% \mathrm{SiC}), \mathrm{Al} /(10 \% \mathrm{SiC})$, $\mathrm{Al} /(5 \%$ fly ash $)$ and $\mathrm{Al} /(10 \%$ fly ash $)$. Here, the particles were segregated at the selected places of the plates. The outer of the casting contained few particles. This is due to the gravity-regulated segregation of the particles. But uniform distributions of particles were observed in the micrographs of aluminium in the presence of SiC-fly ash mixture at various concentrations.

Here, particles were present more throughout the casting. The particle distribution strongly influences the physical and mechanical properties of the composites. The result shows that volume percentage of reinforcement increases with the addition of magnesium, $\mathrm{SiC}$ and fly ash to the melt.

\subsection{X-Ray Diffraction Analysis}

The addition of SiC, fly ash and SiC-fly ash mixture are expected to react with liquid metal and to produce reaction products of various types. The strengthening of the composites is influenced by the nature of the reinforcing phase. Hence there is necessity of identification of the compound produced by the chemical reaction; X-Ray diffraction studies have been used for this purpose. Ou of all, the XRD analysis of the $\mathrm{Al} /(10 \%$ $\mathrm{SiC}+10 \%$ fly ash) composite is shown in Fig. 16 .

XRD spectrum shows the presence of reacted $\mathrm{SiC}$, fly ash and SiC-fly ash mixture. The presence of aluminium, magnesium, SiC and fly ash indicates the possible reaction, which has taken place between the mixture ( $\mathrm{SiC}$ and fly ash) and the aluminium-magnesium alloy.

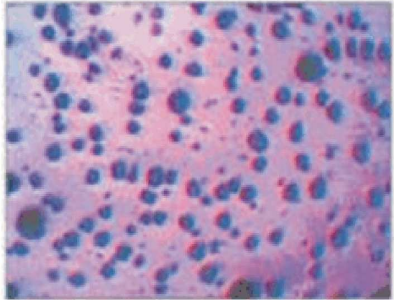

(a)

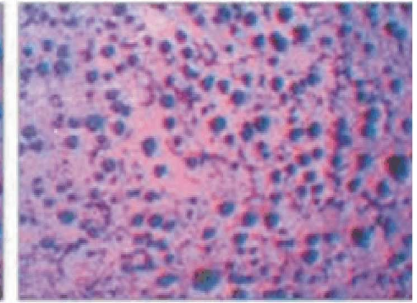

(b)
Fig. 7. Optical micrograph (100X) of pure Al 2024. (a) before etching and (b) after etching

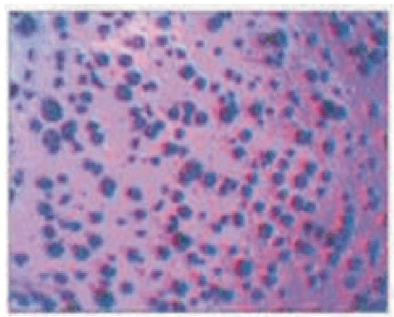

(a)

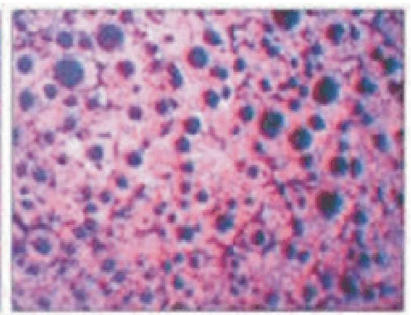

(b)
Fig. 8. Optical micrograph (100X) of Al $2024 /(5 \% \mathrm{SiC})$. (a) before etching and (b) after etching

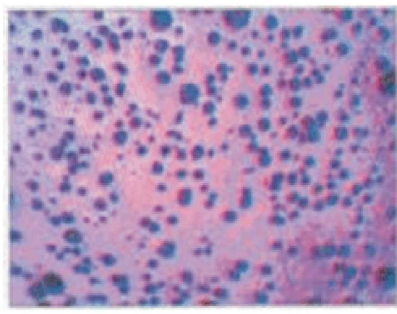

(a)

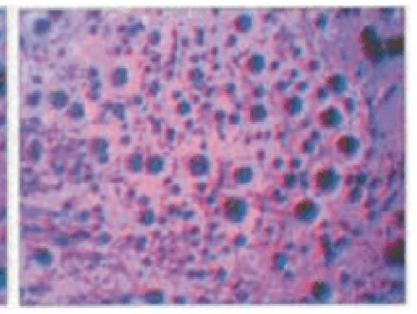

(b)
Fig. 9. Optical micrograph (100X) of $\mathrm{Al} 2024 /(10 \% \mathrm{SiC})$. (a) before etching and (b) after etching

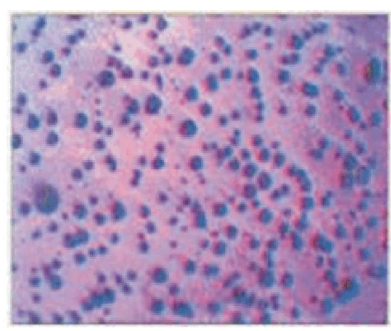

(a)

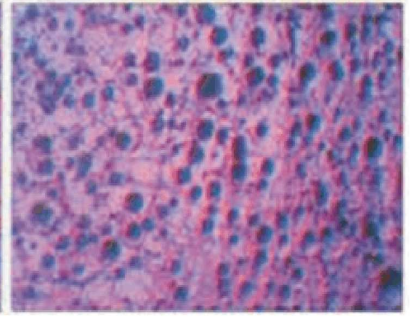

(b)
Fig. 10. Optical micrograph (100X) of Al 2024/(5\% fly ash). (a) before etching and (b) after etching 


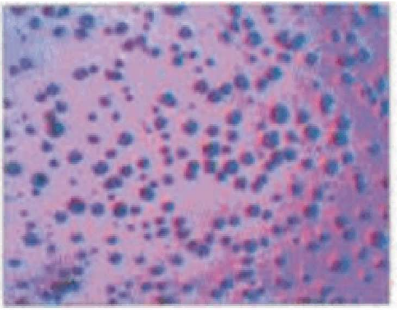

(a)

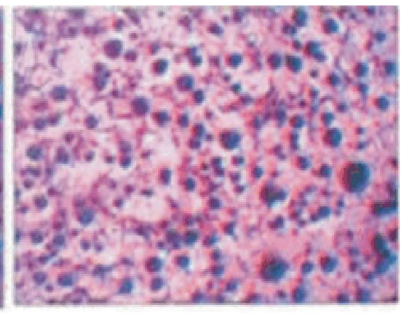

(b)
Fig. 11. Optical micrograph (100X) of Al 2024/(10\% fly ash). (a) before etching and (b) after etching

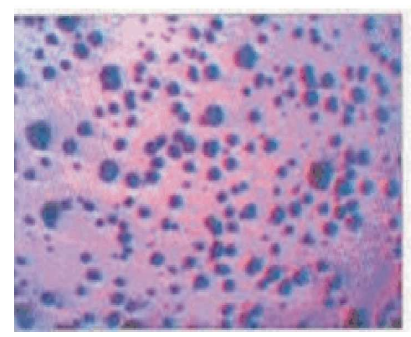

(a)

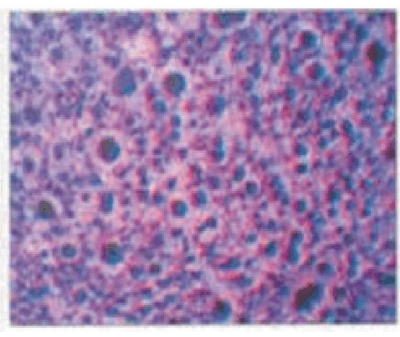

(b)
Fig. 12. Optical micrograph (100X) of $\mathrm{Al} 2024 /(5 \% \mathrm{SiC}+5 \%$ fly ash). (a) before etching and (b) after etching

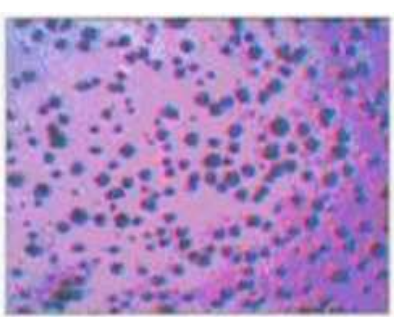

(a)

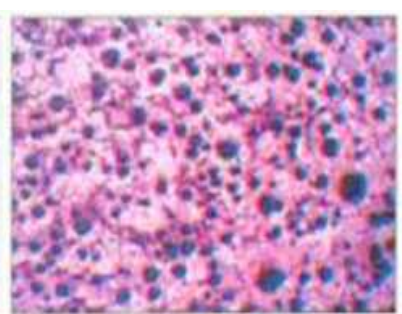

(b)
Fig. 13. Optical micrograph (100X) of $\mathrm{Al} 2024 /(5 \% \mathrm{SiC}+10 \%$ fly ash). (a) before etching and (b) after etching

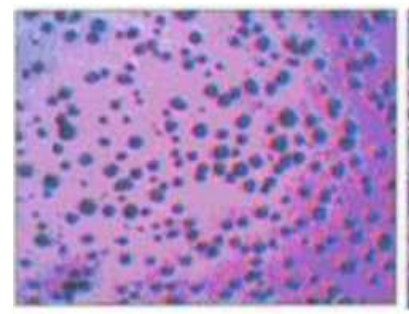

(a)

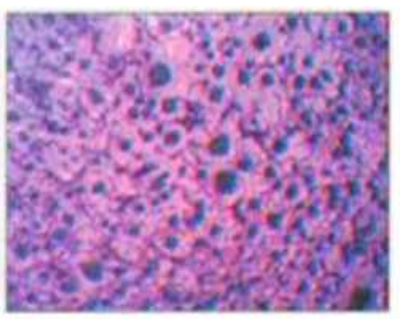

(b)
Fig. 14. Optical micrograph (100X) of $\mathrm{Al} 2024 /(10 \% \mathrm{SiC}+5 \%$ fly ash). (a) before etching and (b) after etching

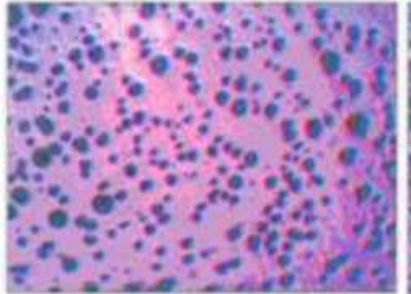

(a)

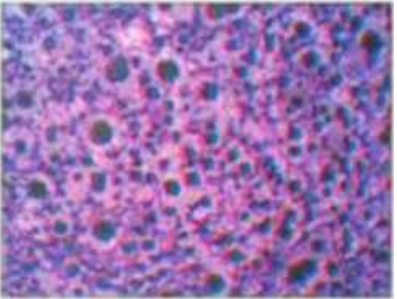

(b)
Fig. 15. Optical micrograph (100X) of $\mathrm{Al} 2024 /(10 \% \mathrm{SiC}+10 \%$ fly ash). (a) before etching and (b) after etching

\subsection{Mechanical Properties}

Results of the mechanical properties of the hybrid metal matrix composites are shown in the Table $\mathbf{1}$.

\subsection{Density}

The graph of the experimental densities of the composites according to the $\mathrm{SiC}$, fly ash and their mixtures is shown in Fig. 17.

Generally the SiC and fly ash particles are having low density compared with aluminium. In the present study, both SiC and fly ash particles were used with a density less than $2.2 \mathrm{~g} / \mathrm{cm}^{3}$. The density of the composite specimens was determined experimentally by the Archimedes principle. The small pieces cut from the specimens were weighed first in air and then water and density values were calculated using the following expression:

$$
\rho=\frac{\text { weight in air }}{\text { weight in air }- \text { weight in water }} \times \rho_{\text {water }}
$$

It was observed (Table 1) that the experimental density values of the Al-SiC, Al-fly and Al-SiC-fly ash composites decreased linearly. The decrease in density of composites can be attributed to lower density of $\mathrm{SiC}$, fly ash and SiC-fly ash particles than that of the unreinforced $\mathrm{Al}$. It was also noted that the theoretical values closely matches with the experimental values. This indicates that the interface between matrix and reinforcement was almost perfectly bonded. Similar results were observed by Rao et al. (2010) and Gnjidi et al. (2001). It is therefore, to improve the density again, apart from Al$\mathrm{SiC}$ and $\mathrm{Al}$-fly ash composites, the mixture of $\mathrm{SiC}$ and fly ash particles were added with aluminium. At higher concentration $[(\mathrm{Al} /(10 \% \mathrm{SiC}+10 \%$ fly ash $)]$, the density was decreased $2.06 \mathrm{~g} / \mathrm{cm}^{3}$. It is about $54 \%$ improvement when compared pure aluminium. 


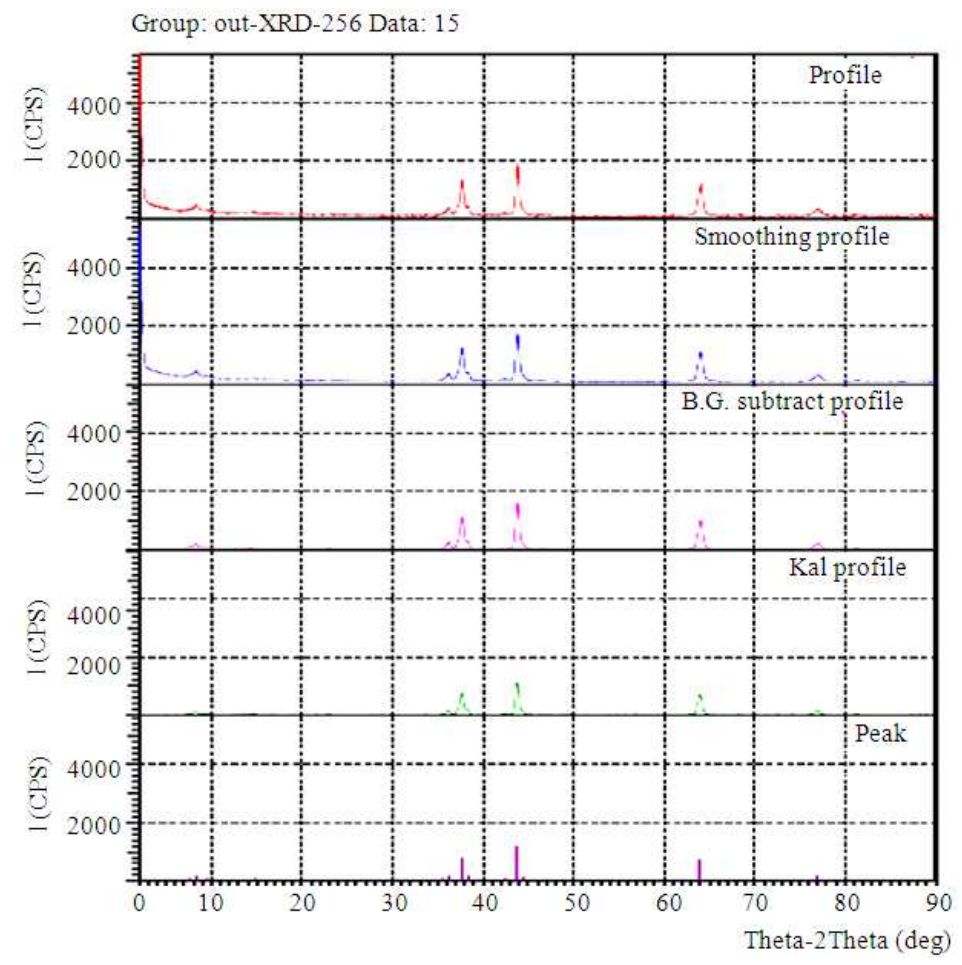

Fig. 16. XRD spectra of the hybrid metal matrix $[\mathrm{Al} /(10 \% \mathrm{SiC}+10 \%$ fly ash $)]$ composites

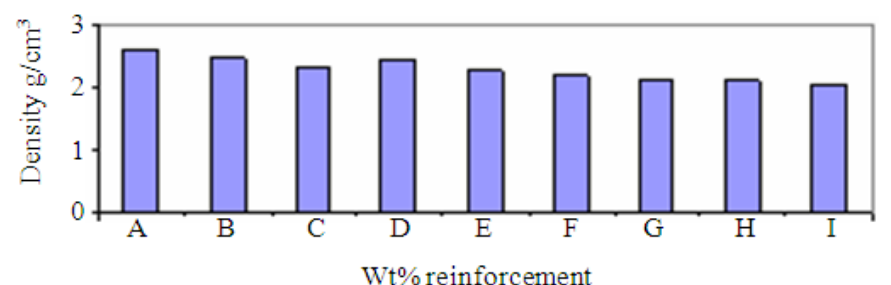

Fig. 17. Graph showing variation in density with different composition $(A=A l, B=A l+5 \% \mathrm{SiC}, \mathrm{C}=\mathrm{Al}+10 \% \mathrm{SiC}, \mathrm{D}=\mathrm{Al}+5 \%$ fly ash, $\mathrm{E}=\mathrm{Al}+10 \%$ fly ash, $\mathrm{F}=\mathrm{Al}+5 \% \mathrm{SiC}+5 \%$ fly ash, $\mathrm{G}=\mathrm{Al}+5 \% \mathrm{SiC}+10 \%$ fly ash, $\mathrm{H}=\mathrm{Al}+10 \% \mathrm{SiC}+5 \%$ fly ash, $\mathrm{I}=$ $\mathrm{Al}+10 \% \mathrm{SiC}+10 \%$ fly ash) of hybrid MMCs

Table 1. Mechanical properties of the hybrid metal matrix composites

\begin{tabular}{|c|c|c|c|c|c|c|c|c|c|}
\hline \multirow{3}{*}{$\begin{array}{l}\text { Sample } \\
\text { No. }\end{array}$} & \multicolumn{4}{|c|}{ Composition } & \multicolumn{5}{|l|}{ Results } \\
\hline & \multirow{2}{*}{$\begin{array}{l}\mathrm{Al}(\%) \\
\text { grams }\end{array}$} & \multicolumn{3}{|c|}{ Wt in $\%$} & \multirow{2}{*}{$\begin{array}{l}\text { Density } \\
\mathrm{g} / \mathrm{cm}^{3}\end{array}$} & \multirow{2}{*}{$\begin{array}{l}\text { Tensile } \\
\text { strength } \\
\mathrm{N} / \mathrm{mm}^{2}\end{array}$} & \multirow{2}{*}{$\begin{array}{l}\text { Yield } \\
\text { strength } \\
\mathrm{N} / \mathrm{mm}^{2}\end{array}$} & \multirow{2}{*}{$\begin{array}{l}\text { Elongation } \\
\text { in } \%\end{array}$} & \multirow{2}{*}{$\begin{array}{l}\text { Hardness } \\
(\mathrm{BHN})\end{array}$} \\
\hline & & $\mathrm{Mg}$ & $\mathrm{SiC}$ & Fly ash & & & & & \\
\hline 1 & 100 & 1.5 & 0 & 0 & 2.6000 & 236 & 220 & 19.4 & 79.9 \\
\hline 2 & 100 & 1.5 & 5 & 0 & 2.4660 & 248 & 236 & 19.0 & 85.3 \\
\hline 3 & 100 & 1.5 & 10 & 0 & 2.3125 & 265 & 257 & 18.2 & 87.2 \\
\hline 4 & 100 & 1.5 & 0 & 5 & 2.4400 & 245 & 233 & 16.3 & 80.6 \\
\hline 5 & 100 & 1.5 & 0 & 10 & 2.2700 & 263 & 252 & 15.8 & 83.8 \\
\hline 6 & 100 & 1.5 & 5 & 5 & 2.2000 & 276 & 262 & 14.4 & 88.2 \\
\hline 7 & 100 & 1.5 & 5 & 10 & 2.1250 & 278 & 269 & 13.8 & 89.7 \\
\hline 8 & 100 & 1.5 & 10 & 5 & 2.1170 & 285 & 275 & 12.8 & 93.9 \\
\hline 9 & 100 & 1.5 & 10 & 10 & 2.0600 & 293 & 287 & 11.9 & 95.7 \\
\hline
\end{tabular}




\subsection{Tensile Strength}

The reinforcing phase in the metal matrix composites bears a significant fraction of stress, as it is generally much stiffer than the matrix. Microplasticity in MMCs that takes place at fairly low stress has been attributed to stress concentrations in the matrix at the poles of the reinforcement and/or at sharp corners of the reinforcing particles (Corbin and Wilkinson, 1994). The increase in volume fraction of reinforcing particles initially decreases the microyielding stress due to increase in number of stress concentration points (Chawla, 2006). Mechanical behavior of Al-SiC and Al-fly ash particles were already reported (Hashim et al., 1999; Quin et al., 1999; Kok, 2005; Doel et al., 1993; Pathak et al., 2006; Sudarshan and Surappa, 2008).

The graph of the experimental tensile strength of the composites according to the $\mathrm{SiC}$, fly ash and their mixtures is shown in Fig. 18. Results show that the tensile strength of composites is higher than that obtained for the unreinforced Al. Tensile strength of unreinforced $\mathrm{Al}$ is $236 \mathrm{~N} / \mathrm{mm}^{2}$ and this value increases to $265 \mathrm{~N} / \mathrm{mm}^{2}$ for $\mathrm{Al} /(10 \% \mathrm{SiC}), 263 \mathrm{~N} / \mathrm{mm}^{2}$ for $\mathrm{Al} /(10 \%$ fly ash) and $293 \mathrm{~N} / \mathrm{mm}^{2}$ for $\mathrm{Al} /(10 \% \mathrm{SiC}+10 \%$ fly ash $)$ composite, which is about $57 \%$ improvement over that of the unreinforced $\mathrm{Al}$ matrix.

\subsection{Yield Strength}

The graph of the experimental yield strength of the hybrid metal matrix composites according to the $\mathrm{SiC}$, fly ash and their mixtures is shown in Fig. 19.

Results show that the yield strength of composites is higher than that obtained for the unreinforced Al. Yield strength of unreinforced $\mathrm{Al}$ is $220 \mathrm{~N} / \mathrm{mm}^{2}$ and this value increases to $257 \mathrm{~N} / \mathrm{mm}^{2}$ for $\mathrm{Al} /(10 \% \mathrm{SiC}), 252 \mathrm{~N} / \mathrm{mm}^{2}$ for $\mathrm{Al} /(10 \%$ fly ash $)$ and finally $287 \mathrm{~N} / \mathrm{mm}^{2}$ for $\mathrm{Al} /(10 \% \mathrm{SiC}+10 \%$ fly ash $)$ composite which is about $67 \%$ improvement over that of the unreinforced aluminium.

\subsection{Elongation}

Figure 20 shows the graph of the experimental elongation of the composites according to the SiC, fly ash and their mixtures. It is experimentally observed that the elongation of composites is gradually decreased than that obtained for the unreinforced aluminium. Elongation of unreinforced $\mathrm{Al}$ is observed as $19.4 \%$, this value is decreased to $18.2 \%$ for $\mathrm{Al} /(10 \% \mathrm{SiC}), 15.8 \%$ for $\mathrm{Al} /(10 \%$ fly ash $)$ and $11.9 \%$ for $\mathrm{Al} /(10 \% \mathrm{SiC}+10 \%$ fly ash) composite which is about $75 \%$ with a reduction of the unreinforced $\mathrm{Al}$ matrix.

\subsection{Hardness}

The graph of the experimental hardness of the composites according to the $\mathrm{SiC}$, fly ash and their mixtures is shown in Fig. 21. As seen from the Fig. 21, an increasing trend of hardness was observed with increase in weight fraction of $\mathrm{SiC}$, fly ash and their mixtures. It is observed that the maximum hardness is observed at $\mathrm{Al} /(10 \% \mathrm{SiC}+10 \%$ fly ash), which might leads to the deformation when subjected to strain. Incorporation of fly ash particles with this significantly improves the hardness and also the deformation of the $\mathrm{Al}$ matrix. It is observed that the fact that the combination of SiC with fly ash particles possess higher hardness than the aluminium.

Thus, it can be concluded that the mechanical properties such as density, tensile strength, yield strength and hardness of the composites increases by increasing $\mathrm{SiC}$, fly ash and their mixtures. Contradictory, elongation of the hybrid metal matrix composite is very much decreased as that of the unreinforced aluminium. Addition of magnesium improves the wettability between the reinforcement particles and enhances the mechanical properties of the composites by solid solution strengthening. In addition, mechanical stirring in the semi solid state enhances the uniform distribution between them.

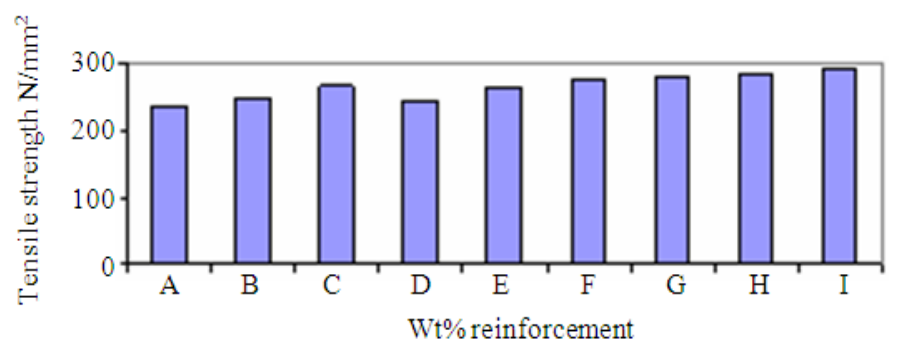

Fig. 18. Graph showing variation in tensile strength with different composition $(\mathrm{A}=\mathrm{Al}, \mathrm{B}=\mathrm{Al}+5 \% \mathrm{SiC}, \mathrm{C}=\mathrm{Al}+10 \% \mathrm{SiC}, \mathrm{D}=$ $\mathrm{Al}+5 \%$ fly ash, $\mathrm{E}=\mathrm{Al}+10 \%$ fly ash, $\mathrm{F}=\mathrm{Al}+5 \% \mathrm{SiC}+5 \%$ fly ash, $\mathrm{G}=\mathrm{Al}+5 \% \mathrm{SiC}+10 \%$ fly ash, $\mathrm{H}=\mathrm{Al}+10 \% \mathrm{SiC}+$ $5 \%$ fly ash, $\mathrm{I}=\mathrm{Al}+10 \% \mathrm{SiC}+10 \%$ fly ash) of hybrid MMCs. 


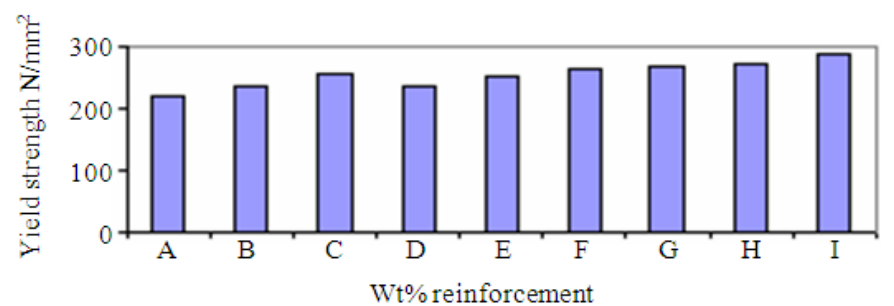

Fig. 19. Graph showing variation in yield strength with different composition $(A=A l, B=A l+5 \% \mathrm{SiC}, \mathrm{C}=\mathrm{Al}+10 \% \mathrm{SiC}, \mathrm{D}=\mathrm{Al}$ $+5 \%$ fly ash, $\mathrm{E}=\mathrm{Al}+10 \%$ fly ash, $\mathrm{F}=\mathrm{Al}+5 \% \mathrm{SiC}+5 \%$ fly ash, $\mathrm{G}=\mathrm{Al}+5 \% \mathrm{SiC}+10 \%$ fly ash, $\mathrm{H}=\mathrm{Al}+10 \% \mathrm{SiC}+5 \%$ fly ash, $\mathrm{I}=\mathrm{Al}+10 \% \mathrm{SiC}+10 \%$ fly ash) of hybrid MMCs

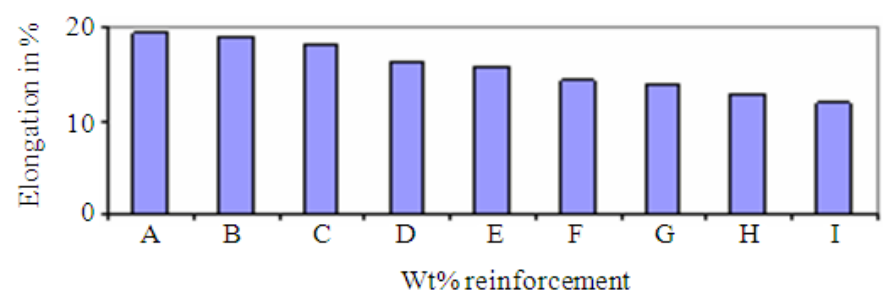

Fig. 20. Graph showing variation in elongation with different composition $(\mathrm{A}=\mathrm{Al}, \mathrm{B}=\mathrm{Al}+5 \% \mathrm{SiC}, \mathrm{C}=\mathrm{Al}+10 \% \mathrm{SiC}, \mathrm{D}=\mathrm{Al}+5 \%$ fly ash, $\mathrm{E}=\mathrm{Al}+10 \%$ fly ash, $\mathrm{F}=\mathrm{Al}+5 \% \mathrm{SiC}+5 \%$ fly ash, $\mathrm{G}=\mathrm{Al}+5 \% \mathrm{SiC}+10 \%$ fly ash, $\mathrm{H}=\mathrm{Al}+10 \% \mathrm{SiC}+5 \%$ fly ash, $\mathrm{I}=\mathrm{Al}+10 \% \mathrm{SiC}+0 \%$ fly ash) of hybrid $\mathrm{MMCs}$

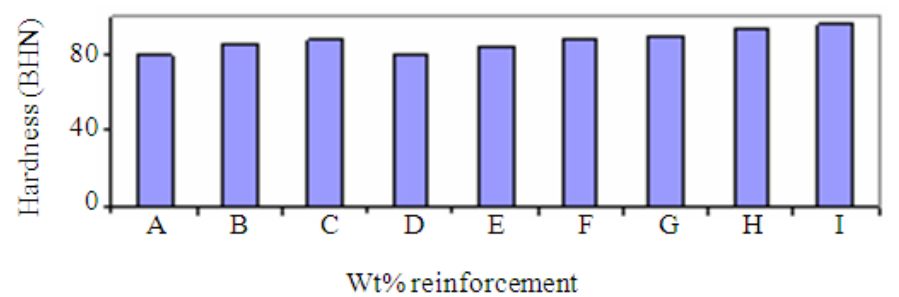

Fig. 21. Graph showing variation in hardness with different composition $(\mathrm{A}=\mathrm{Al}, \mathrm{B}=\mathrm{Al}+5 \% \mathrm{SiC}, \mathrm{C}=\mathrm{Al}+10 \% \mathrm{SiC}, \mathrm{D}=\mathrm{Al}+5 \%$ fly ash, $\mathrm{E}=\mathrm{Al}+10 \%$ fly ash, $\mathrm{F}=\mathrm{Al}+5 \% \mathrm{SiC}+5 \%$ fly ash, $\mathrm{G}=\mathrm{Al}+5 \% \mathrm{SiC}+10 \%$ fly ash, $\mathrm{H}=\mathrm{Al}+10 \% \mathrm{SiC}+5 \%$ fly ash, $\mathrm{I}$ $=\mathrm{Al}+10 \% \mathrm{SiC}+10 \%$ fly ash) of hybrid $\mathrm{MMCs}$

\section{CONCLUSION}

Al-SiC, Al-fly ash, Al-SiC-fly ash (various concentrations) composites were successfully fabricated by two-step stir casting process. Wetting of reinforcements with the aluminium matrix was further improved by the addition of magnesium.

Based on the experimental observations the following conclusions have been drawn:

- Density of the composites decreased by increasing the content of the reinforcement. Hence, it was found that, instead of $\mathrm{Al}-\mathrm{SiC}$ and Al-fly ash composites, Al-SiC-fly ash composites show better performance. So these composites can be used in applications where to a great extent weight reductions are desirable

- Tensile strength, yield strength and hardness were determined for the test materials. Increase in area fraction of reinforcement in matrix result in improved tensile strength, yield strength and hardness

- With the addition of $\mathrm{SiC}$ and fly ash with higher percentage the rate of elongation of the hybrid MMCs is decreased significantly

- Optical micrographs revealed that both the $\mathrm{SiC}$ and flay ash particles are well distributed in aluminium matrix

- $\quad$ XRD results showed negligible changes in contents of constituents 
From the above results we can conclude that instead of $\mathrm{Al}-\mathrm{SiC}$ or Al-fly ash composites, the Al-SiC-fly ash composites could be considered as an exceptional material in sectors where lightweight and enhanced mechanical properties are essential.

\subsection{Scope of the Future Work}

The study can be extended by the addition of other materials with aluminium 2024. Wear and corrosion studies can also be carried out.

\section{REFERENCES}

Brian, R.H., D.B. Hayden and M.A. Powell, 2003. Evaluation of pulverized fuel ash mixed with organic matter to act as a manufactured growth medium. University of Western Ontario.

Buraimoh, A.A., S.A. Ojo, J.O. Hambolu and S.S. Adebisi, 2012. Aluminium chloride exposure had no effects on the epididymis of wistar rats. Am. Med. J., 3: 210-219. DOI: 10.3844/amjsp.2012.210.219

Chawla, N., 2006. Metal matrix composites in automotive applications. Adv. Mater. Processes., 164: 29-31.

Corbin, S.F. and D.S. Wilkinson, 1994. The influence of particle distribution on the mechanical response of a particulate metal matrix composite. Acta Metall. Mater., 42: 1311-1318. DOI: 10.1016/09567151(94)90147-3

Doel, T.J.A., M.H. Lorretto and P. Bowen, 1993. Mechanical properties of aluminium-based particulate metal-matrix composites. Composites, 24: 270-275. DOI: 10.1016/0010-4361(93)90174-7

Gatima, E., M. Mwinyihija and K. Killham, 2005. Assessment of Pulverised Fly Ash (PFA) as an ameliorant of lead contaminated soils. Am. J. Environ. Sci., 1: 230-238.

Gnjidi, Z., D. Boi and M. Mitkov, 2001. The influence of $\mathrm{SiC}$ particles on the compressive properties of metal matrix composites. Mater. Character., 147: 129-138. DOI: 10.1016/S1044-5803(01)00161-9

Hashim, J., L. Looney and M.S.J. Hashmi, 1999. Metal matrix composites: Production by the stir casting method. J. Mater. Process. Technol., 92: 1-7. DOI: 10.1016/S0924-0136(99)00118-1

Ibrahim, I.A., F.A. Mohamed, E.J. Lavernia, 1991. Metal matrix composites-a review. J. Mater. Sci., 26: 1137-1157. DOI: 10.1007/BF00544448
Kok, M., 2005. Production and mechanical Properties of $\mathrm{Al}_{2} \mathrm{O}_{3}$ particle-reinforced 2024 aluminium alloy composites. J. Mater. Process. Technol., 161: 381-387. DOI: 10.1016/j.jmatprotec.2004.07.068

Mohan, S.K.R., K.P. Jayabalan and A. Rajaraman, 2012. Properties of fly ash based coconut fiber composite. Am. J. Eng. Applied Sci., 5: 29-34. DOI: 10.3844/ajeassp.2012.29.34

Nai, S.M.L. and M. Gupta, 2002. Influence of stirring speed on the synthesis of $\mathrm{Al} / \mathrm{SiC}$ based functionally gradient materials. Compos. Struct., 57: 227-233. DOI: $10.1016 / \mathrm{S} 0263-8223(02) 00089-2$

Neudeck, P.G., 1992. An overview of silicon carbide technology. National Aeronautics and Space Administration.

Pai, B.C., T.P.D. Rajan and R.M. Pillai, 2004. Aluminium matrix composite castings for automotive applications. Ind. Foundry J., 50: 30-39.

Pathak, J.P., J.K. Singh and S. Mohan, 2006. Synthesis and characterisation of aluminium-silicon-silicon carbide composite. Ind. J. Eng. Mater. Sci., 13: 238246.

Prabu, S.B., L. Karunamoorthy, S. Kathiresan and B. Mohan, 2006. Influence of stirring speed and stirring time on distribution of particles in cast metal matrix composite. J. Mater. Process. Technol., 171: 268273. DOI: 10.1016/j.jmatprotec.2005.06.071

Quin, S., C. Chen, G. Zhang, W. Wang and Z. Wang, 1999. The effect of particle shape on ductility of $\mathrm{SiCp}$ reinforced $6061 \mathrm{Al}$ matrix composites. Mater. Sci. Eng., 272: 363-370. DOI: 10.1016/S09215093(99)00503-1

Rao, J.B., D.V. Rao and N.R.M.R. Bhargava, 2010. Development of light weight ALFA composites. Int. J. Eng. Sci. Technol., 2: 50-59.

Sannino, A.P. and H.J. Rack, 1995. Dry sliding wear of discontinuously reinforced aluminum composites: Review and discussion. Wear, 189: 1-19. DOI: 10.1016/0043-1648(95)06657-8

Sarkar, S. and A. Singh, 2012. Studies on aluminum-iron ore in-situ particulate composite. Open J. Comp. Mater., 2: 22-30. DOI: 10.4236/ojcm.2012.21004

Sinclair, I. and P.J. Gregson, 1997. Structural performance of discontinuous metal matrix composites. Mater. Sci. Technol., 3: 709-726. DOI: $10.1179 / 026708397790290254$ 
Sudarshan and M.K. Surappa, 2008. Synthesis of fly ash particle reinforced A356 Al composites and their characterization. Mater. Sci. Eng. A, 480: 117-124. DOI: $10.1016 /$ j.msea.2007.06.068

Surappa, M.K., 2003. Aluminium matrix composites: Challenges and opportunities. Sadhana, 28: 319-334. DOI: $10.1007 / \mathrm{BF} 02717141$
Ulrichs, C., U. Schmidt, T. Mucha-Pelzer, A. Goswami and I. Mewis, 2009. Hard coal fly ash and silicaeffect of fine particulate matter deposits on brassica chinensis. Am. J. Agric. Biol. Sci., 4: 24-31. DOI: 10.3844/ajabssp.2009.24.31 